\title{
Author Correction: Genomic evidence of past and future climate-linked loss in a migratory Arctic fish
}

K. K. S. Layton (D, P. V. R. Snelgrove (D), J. B. Dempson, T. Kess, S. J. Lehnert (D, P. Bentzen (D), S. J. Duffy, A. M. Messmer,

R. R. E. Stanley (D), C. DiBacco, S. J. Salisbury (D), D. E. Ruzzante (D), C. M. Nugent (D), M. M. Ferguson, J. S. Leong (D),

B. F. Koop (iD and I. R. Bradbury (D)

Correction to: Nature Climate Change https://doi.org/10.1038/s41558-020-00959-7, published online 11 January 2021.

In the version of this Article originally published, ref. 84 was an article that has since been retracted; it has now been replaced with "Salvelinus. NCBI https://www.ncbi.nlm.nih.gov/genome/86400 (2021)." This change does not alter the results or findings of the study.

The online versions of the Article have been corrected.

Published online: 17 March 2021

https://doi.org/10.1038/s41558-021-01023-8

(C) The Author(s), under exclusive licence to Springer Nature Limited 2021

\section{Publisher Correction: Projected shifts in the foraging habitat of crabeater seals along the Antarctic Peninsula}

Luis A. Hückstädt (D), Andrea Piñones, Daniel M. Palacios (D), Birgitte I. McDonald, Michael S. Dinniman (D),

Eileen E. Hofmann, Jennifer M. Burns DD, Daniel E. Crocker and Daniel P. Costa

Correction to: Nature Climate Change https://doi.org/10.1038/s41558-020-0745-9, published online 27 April 2020.

In this Article originally published, the received and accepted dates were missing. "Received: 20 January 2019; Accepted: 6 March 2020"

has now been added to the online versions of the Article.

Published online: 7 April 2021

https://doi.org/10.1038/s41558-021-01036-3

(c) The Author(s), under exclusive licence to Springer Nature Limited 2021 